Barford, A., 2009. World poverty - what can we do about it? Geography, v.94, 215-218.

\title{
World poverty - what can we do about it?
}

\author{
Anna Barford \\ Department of Geography, University of Sheffield, Winter Street, Sheffield, S10 2TN.
}

Geography department telephone: 01142227973.

Geography department fax: 01142797912

Anna.Barford@sheffield.ac.uk

Word count: 2618 (entire word document)

Keywords: poverty, discourse, labelling, history, change 


\section{ABSTRACT}

In this article I argue that the way poverty is framed in mainstream politics and media illuminates some aspects of the issue, while obscuring others. This framing could actually contribute to the situations in which poor people live worldwide not improving, as efforts may not be addressing the real causes of poverty. Re-thinking how we talk about poverty, one of the most pressing issues of our time, can help us to see what is missing from dominant explanations of poverty. This essay gives an insight into the history of the concept of "the poor", and presents some critiques of thinking on poverty and of actions to alleviate poverty.

\section{INTRODUCTION: THINKING ABOUT THE POOR}

Could the question 'what should we do about world poverty?' be part of the problem? Perhaps our way of asking this important question is unhelpful. 'The poor' implies the problems of a certain group in society, rather than the underlying social and economic processes. Thinking only about 'poverty' means that we overlook the many connections between different income groups, and the important issues of wealth distribution that create and maintain poverty. This way of thinking can obscure the structural forces that result in some people having less access to resources than others (i.e. wider social forces such as the economy, the way we value different types of work, and the trade rules that we play by). There are also important issues about how we define who is poor. Powerful people define and measure poverty, thus naming and defining the social position of less powerful people. Arguably, some approaches to alleviating poverty classify people in a manner that actually reduces poorer people's control over their own lives. Here I challenge one dominant way of speaking about poverty. 
I will outline some problems with the current way we think and speak about poverty, consider how some academics think about this, and what we can do to challenge this. The aim is not to deny the existence of unnecessary suffering from a lack of access to basic resources such as food security, durable shelter, and a safe environment. I aim to consider the problems arising from how we talk about issues, and propose some alternatives. This sort of thinking is called 'critical discourse analysis', which may sound daunting, but is a fantastic way to reconsider how we talk about the world. When we think about how we talk about the world, we can also think about what we are leaving out. Once you've got the idea, you can try to apply it to other examples (how we talk about the differences between men and women, or media reporting of events).

\section{A BRIEF HISTORY OF POVERTY DISCOURSE}

Critical discourse analysis questions the foundations of the ideas that we use to organise society, and the world. For example, because we have the names for regions 'Europe', 'Africa', 'Latin America' they allow us to easily discuss that region as an entity. If we did not have a word 'Latin America' it would take so long to list all the countries before making a statement about them. These region names make it is easy to think of regions. Language can make concepts seem natural, and therefore powerful, to our way of thinking. Is it ridiculous to imagine that 'Latin America' could not exist in our language? If we look five centuries back in history - before the time of the 'conquistadors' from the Iberian Peninsula - we realise that Latin America has not always existed. No Latin-based languages were spoken there, 'Latin' America did not exist. Nor for that matter did 'America' ${ }^{1}$.

\footnotetext{
${ }^{1}$ Of course the name America is also relatively recent. Perhaps you could look into the history of name and think about where 'America' refers to. Also, what other
} 
Looking to history helps us to understand how our current ideas have been constructed (as Geographers we can learn a lot from historians, as well as economists, anthropologists, sociologists and natural scientists). First we will consider the work of the historian Keith Thomas. There is a close connection between the enclosure of land during the early modern period in England and the idea of the pauper. In the mid 1500s (the same time as Spanish and Portugal were 'Latinising' parts of America), manorial estates in England became increasingly private. Previously whole families would have been supported by the manor, could have slept in the barns, and had rights to food from the fields. Then, actions that were once rights became criminalised. After this change, it was thought that the poor should look after themselves and dependency came to be seen negatively (Thomas, 1997). The rich have always been dependent upon the labour of those who are poorer than them: to farm, cook, clean, and much more. However what is criticised is the 'dependency' of poorer people, and wealthy people are rarely described as dependent.

In 1902, during a period of heightened interest in social problems and poverty, B. Seebohm Rowntree proposed a 'poverty line' based on the minimum income necessary to achieve "physical efficiency", which included living costs for housing rent, food, and other necessities. His work was based in York. His use of the measure of income strongly hinted that if low income caused poverty, then higher income could alleviate it (O'Connor, 2001). Despite Rowntree's good intentions, in identifying people unable to support themselves financially, the idea of a 'poverty line' is now criticised by some. But what is this line, how little income do 'officially poor' people have? According to The World Bank, one of the most prominent organisations that defines poverty for the rest of the world:

names and ideas existed about this land amongst the people already living there when it was 'discovered'? 
“... for the purpose of global aggregation and comparison, the World Bank uses reference lines set at \$1 and \$2 per day (more precisely \$1.08 and \$2.15 in 1993 Purchasing Power Parity terms). It has been estimated that in 2001, 1.1 billion people had consumption levels below $\$ 1$ a day and 2.7 billion lived on less than $\$ 2$ a day." (The World Bank, 2008).

Poverty lines are based on various assumptions. Consider the process of measuring poverty between countries. Firstly you need to know what basic requirements people have: housing, food and entertainment. Choose some items, perhaps include rent, a bag of rice, a loaf of bread, vegetables, fruit, and a newspaper. Then calculate the cost of this "daily shopping basket" for each country. (Even within countries living costs vary: for example renting a comparable house can cost twice as much in London as in Sheffield; this adds an imperfection to your calculation.) Secondly, standardise these prices so that you can compare between countries, here US dollars are used. However, US\$1 is harder to earn and buys more in poorer countries than in richer countries: that is why it is cheap for Brits to go travelling in India, why many Mexican people work in the USA and send money home, and part of the reason goods are often manufactured for a low financial cost in poorer countries. Also, conventional dollars are not a suitable measure because the poverty line would fluctuate with exchange rates. So, invent a new measure! It's called Purchasing Power Parity US dollars (PPP US\$). Theoretically PPP US\$1 buys the same "daily shopping basket" wherever you are in the world, and the value of the money is equivalent to spending US\$1.08 in the USA in 1993. Lastly, you need to identify the threshold for poverty in PPP US\$ and calculate how many people earn less than that: a threshold of PPP US\$2 per day would mean that 2.7 billion people were poor in 2001, according to the World Bank.

\section{LABELLING THE POOR}


Some academics, including anthropologist Vigdis Due-Broch, argue against the World Bank categorisations of people as 'poor'. Her argument is that labelling people as poor can be essentialising (it makes you think of only one element of someone's life) and generalising (poor people are seen as all being the same because they have this one common attribute). Further, in this way poor people are defined as poor by others. Someone from outside has come to them with their own measures and ideas of what is valuable, collected information, and later defined them as poor: objects of the war on poverty. Here the problem is the onesided nature of this relationship (Due-Broch, 2008).

Here is a story to illustrate how culturally specific poverty definitions can be. A United Nations poverty researcher went to Bangladesh to measure poverty levels there. The Bangladeshi women she met asked her, "How many children do you have?", she answered "none". They asked, "do you have a husband?", she said "no". So, the women who themselves had husbands and many children, said that they were not poor. Instead the woman who had come to measure poverty was poor, as she neither had children nor a husband. This shows the very narrow and culturally specific nature of the income measure of poverty, and how it overlooks the value of human relationships. Thus someone may be defined as poor by someone else, but not by themselves.

Defining someone as poor often carries additional negative meaning, often in association with ideas of dependency on society. There is a frequent distinction between the deserving and undeserving poor, the behaviour of the "undeserving poor" is often blamed for their poverty (Katz, 1990). An example of this is the idea that people having many children causes them to be poor, whereas this could be seen as a response to high child mortality, or due to a different value being placed on children as in Bangladesh. Katz argues that classifying poor people serves a useful purpose: "They offer a familiar and easy target for displacing rage, frustration and fear. They demonstrate the link between virtue and success that legitimates 
capitalist political economy." Katz, 1990, p.10). Measuring poverty does, importantly, highlight problematic resource distribution between people; still 'the poor' themselves may live being blamed and feared by others. For some 'poor' even implies failure. Distinguishing causes and effects, and recognising the economic, cultural and moral as different, could detach poverty from some of the negative connotations it carries.

The media often shows poor people as a sealed group, outside of the wider socio-economic system within which they are situated. One example of this narrow perspective is the media's treatment of disasters and emergencies, commonly shown with little reference to the underlying causes. People living in humanitarian crises are represented by the media as helpless, feeble and dependent, rather than heroic in their ability to survive in such difficult situations. All this can lead viewers to pity these unfortunate people, rather than thinking of how the root causes could be tackled which could result in hope for the future (Hammock and Charny, 1996).

\section{CONTEMPORARY CONTRADICTION}

The Millennium Development Goal (MDG) 1 aims to halve extreme poverty and hunger by 2015. This aim is concerned with just one segment of the world population, rather than looking at the huge extremes of wealth and poverty. Thus 'the poor' are shown to be 'the problem' that needs solving, rather than the existence of such entrenched differences in wealth and income. As Samir Amin suggests of MDG 1: "This is nothing but an empty incantation as long as the policies that generate poverty are not analyzed and denounced and alternatives proposed." (Amin, 2006, p.3). Amin notes that achieving the MDGs is assumed to be perfectly compatible with economic liberalism, so the MDGs do not propose any major alterations to the existing world economic system. 
There are many aspects to global rules that allow the continued accumulation of wealth amongst some, which contributes to the poverty of others. For example natural resources are often owned by companies, rather than the local populace. Thus owners of companies benefit from the sales of oil, metal ores and food, because they own the means of production, whilst people who live nearby and even work for the companies concerned benefit little. Another example is the agricultural protectionism used by people in rich countries against poor countries - annually US\$ 350 billion is spent to subsidise farmers in rich countries so that their products will sell better than those from poor countries Pogge, 2008). These are just two examples of how people in economically powerful positions are connected to the lives of 'the poor'. Thus, in thinking about poverty it is illuminating to question the relationships create and maintain it.

\section{CONCLUSION}

So in response to the question "what can we do about poverty?" my personal response is as follows. Instead of thinking about 'the poor' as a problem to be solved, we need to think about the connections between people, including ourselves: we are involved in the processes that create poverty. It is not necessary to go abroad as a volunteer to help people in poor countries (anyway, poverty is also an issue within the U.K.). Instead, it could be helpful to think about how our own governments are involved in making rules that keep some people poor and others rich. When talking about poverty, I will be careful not to speak about 'the poor' as if they were disconnected from the rest of society, but phrase the issue in terms of inequalities, thus recognising that we are all involved. By changing the terms of discussion to include the history, international connections, inequality and mutual responsibility, the questions that I am able to ask about how and why poverty exists will 
change. Perhaps by thinking about poverty in different ways we can generate new types of questions and answers about how to overcome such an unjust social situation.

IMAGE CAPTION: Woman begging at traffic lights. Guadalajara, Mexico

\section{ACKNOWLEDGEMENTS}

Many of the ideas and arguments expressed here have been discussed and developed at the 2008 Bergen Summer Research School on Global Development Challenges. I thank my teachers (Vigdis Due-Broch, Alice O'Connor and Jean Comaroff) and classmates for the stimulating learning environment.

\section{QUESTION}

Do you have any ideas about how we could think differently about poverty and inequalities? What should be done to address these issues? (please email your answers to me: Anna.Barford@sheffield.ac.uk).

\section{SUGGESTED READING}

The poverty discourse discussed above is not the only one. Here are some others. Compare the different perspectives on inequalities offered in the following:

United Nations Millennium Development Goals. http://www.un.org/millenniumgoals/

The World Development Movement. http://www.wdm.org.uk/about/ 
Noam Chomsky's short video on 'Rethinking Capitalism'.

http://www.adbusters.org/blogs/blackspot/noam chomsky rethinking capitalism.html

\section{REFERENCES}

AMIN, SAMIR (2006) The millennium development goals: a critique from the south. Monthly Review, 57, 1-9.

DUE-BROCH, VIGDIS (2008) Global reconfigurations of Poverty and the Public: Lecture. Bergen Summer Research School. University of Bergen.

HAMMOCK, JOHN C \& CHARNY, JOEL R (1996) Emergency response as morality play: the media, the relief agencies, and the need for capacity building. IN ROTBERG, R. I. \& WEISS, T. G. (Eds.) From massacres to genocides: the media, public policy and humanitarian crises. Cambridge, Massachusetts, World Peace Foundation.

KATZ (1990) The undeserving poor, London, Pantheon Books.

O'CONNOR, ALICE (2001) Poverty Knowledge: Social Science, Social Policy, and the Poor in Twentieth-Century U.S. History, Princeton, Princeton University Press.

POGGE, THOMAS (2008) Global Justice and Global Development Challenges. Bergen Summer Research School. University of Bergen.

THE WORLD BANK PovertyNet, Date Accessed: 14.08.2008,

THOMAS, KEITH (1997) Religion and the Decline of Magic: Studies in popular beliefs in sixteenth and seventeenth century England, Oxford, Oxford University Press. 